\author{
Gisele Iulianelli, Maria Bruno Tavares and Leandro Luetkmeyer
}

\title{
WATER ABSORPTION BEHAVIOR AND IMPACT STRENGTH OF PVC/WOOD FLOUR COMPOSITES
}

\author{
Instituto de M acromoleculas Professora Eloisa M ano, Universidade Federal do Rio de Janeiro, \\ CT, bloco J, Cidade Universitaria, Ilha do Fundao, CP 68525, CEP 21945-970, \\ Rio de Janeiro, R.J., Brazil; gisele@ima.ufrj.br
}

Received: September 09, 2009 / Accepted: M ay 19, 2010

○ Iulianelli G., Tavares M.B., Luetkmeyer L., 2010

\begin{abstract}
PVC/wood flour composites were prepared by compression molding using sapwood and heartwood from Angelin Pedra as filler. The composites specimens were subjected to water immersion and impact tests. The results showed that the water absorption of all composites increased slightly with increasing immersion time and wood content. However, the values were considerably low compared with control sample, common solid woods and wood plastic composites reported in literature. PVC/sapwood composites showed slightly higher values for moisture absorption ability due to the difference in chemical constituents' ratio. PVC compound and PVC/sapwood composite containing $10 \mathrm{phr}$ of wood flour exhibited maximum water absorption in 63 days and it corresponded to $0.25 \%$ and $0.58 \%$ weight gain, respectively. In relation to impact test, the results indicated that impact property was affected by wood content and less by wood type. Composites containing $10 \mathrm{phr}$ of wood content showed greater impact strength (decreased by around $60 \%$ ) than those prepared with 25 and $40 \mathrm{phr}$ of wood flour content (decreased approximately by $75 \%$ ). In general the composites prepared with $10 \mathrm{phr}$ of wood flour content exhibited a better performance in both parameters measured in this study.
\end{abstract}

Keywords: PVC, Angelin Pedra, wood plastic composites, water absorption, impact strength.

\section{Introduction}

A more recent development in composite technologies is wood/plastic composites (WPCs). Developed by small entrepreneurs and multi-national oil companies, these materials attempt to take advantage of the properties of both materials [1]. The reinforcement of thermoplastics by means of cellulosic fibers such as wood significantly improves stiffness and strength compared to the neat polymers, at the expense of ductility and impact strength [1-3]. Wood has been widely used to replace reinforcing fillers previously used to fill plastics, such as inorganic materials and synthetic fibers, because it presents several advantages [4]. Compared to these materials, wood presents lower density; less abrasiveness; lower cost and is renewable and biodegradable [5-10]. Moreover, the fact that it is obtained directly from natural resources makes it even more attractive in terms of sustainability and environmental awareness.

Water absorption behavior and impact strength has been intensively studied because these are important features that determine end use applications of woodpolymer composites.

Poor resistance of wood to moisture absorption can cause dimensional instability and undesirable effects on the mechanical properties of these materials [11]. The study of this property in details is fundamental because the woodbased composites are often subjected to the environment where the moisture conditions change rapidly [12].

Impact strength is among the most important properties required for polymers and their modified system including PVC/wood flour composites [2]. Wood type and content, matrix ductility and void content of the composites are the main structural parameters which affect the impact behavior. The impact strength is the ability of a material and its structure to survive impact induced damages during an impact event [13].

In this study we examined moisture absorption behavior and impact strength of PVC/wood flour composites considering as variables wood type and proportion.

\section{Experimental}

\subsection{Matrix Polymer}

Poly(vinyl chloride) SP800 supplied by Norvic was used as the matrix in this study. 


\subsection{Reinforced Filler}

Sapwood and heartwood from Angelin Pedra supplied by University of Mato Grosso, Brazil were used as filler. These two wood types, after being separated, were triturated, bolded in a mesh size 40-80 (0.420$0.177 \mathrm{~mm}$ ) and subject to the heat treatment in an oven at $353 \mathrm{~K}$ for $48 \mathrm{~h}$ to minimize the moisture content before mixing. Drying of wood filler before processing is an important factor, because during processing of natural filler with thermoplastic matrix, the water on the wood surface acts like a separating agent in the wood-matrix interface and also can lead to poor processability and porous product $[14,15]$. The concentrations of the wood flour chemically untreated to the development of the composites were 0 , 10,25 and $40 \mathrm{phr}$ (parts per hundred of resin).

\subsection{Samples and Specimens Preparation}

The PVC powder was dry-blended with some additives as listed in Table 1, to give PVC compound and composites. The formulations were prepared by Haake Rheocord 900 fixed with $438 \mathrm{~K}$ and $50 \mathrm{rpm}$. The PVC compound was being made for $7 \mathrm{~min}$ without interruption. The preparation of the composites was made in two steps: the PVC compound ingredients were being mixed for 5 min and immediately the filler was added and the mixing was continued for 2 min.

For water absorption measurements, discs specimens $\left(2.6 \times 6.0 \mathrm{~cm}^{3}\right)$ were prepared, and for impact test the dimensions of the specimens were $61 \mathrm{~mm}$ long, $12.7 \mathrm{~mm}$ wide and $3 \mathrm{~mm}$ thick. All specimens were prepared by compression molding at $453 \mathrm{~K}$ during $20 \mathrm{~min}$ and conditioned at $296 \pm 2 \mathrm{~K}$ and $50 \pm 5 \%$ relative humidity for at least $48 \mathrm{~h}$ in accordance with Procedure A of method ASTM D618.

Table 1

Ingredients of PVC compound and composites

\begin{tabular}{|l|c|}
\hline \multicolumn{1}{|c|}{ Ingredients } & $\begin{array}{c}\text { Concentration, } \\
\text { phr }\end{array}$ \\
\hline Resin PVC (Norvic $®$ SP800) & 100 \\
\hline Stabilizer (Naftosafe® CZ-4004) & 4 \\
\hline Processing aids (MMA-co-EA K12) & 1 \\
\hline Impact modifier (KaneAce@B52) & 8 \\
\hline Wood flour (sapwood or heartwood) & $0,10,25,40$ \\
\hline
\end{tabular}

\subsection{Water Absorption Test}

The samples were air dried at $323 \mathrm{~K}$ up to a constant weight and then immersed in a static deionized water bath. The specimens were taken out of the water at certain periods of time, wiped with tissue paper to remove surface water, reweighed and immediately put back into the water. The water absorption test was conducted according to
ASTM D570 method. At least three specimens for each sample were used and the average values were reported.

The percentage of water absorption (WA) was calculated by the weight difference between the samples exposed to water and the dried samples according to the following equation:

$$
W A(\%)=\frac{M_{e}-M_{0}}{M_{0}} \cdot 100
$$

where: $M \mathrm{e}$ is the mass of the sample after immersion (g) and $M \mathrm{o}$ is the mass of the sample before immersion (g).

The experiment was conducted in relative humidity (RH) equal to $50 \%$ at $296 \pm 1 \mathrm{~K}$, during 70 days and water absorption was determined by weighing on a balance with precision of $0.0001 \mathrm{~g}$.

\subsection{Izod Impact Testing}

Izod impact tests were performed in an Instrumented Impact tester (model Resil Impactor) with $2 \mathrm{~J}$ capacity using notched specimens. The tests were conducted at $298 \mathrm{~K}$ according to ASTM D-256 method. Each mean value represented an average of eight samples.

\subsection{Chemical Characterization of the Woods}

The chemical constituents characterization of the sapwood and heartwood from Angelin Pedra was performed as described in detail in the previous works [16-18]. The analysis was performed in triplicate and the result related to it represents the average values.

\section{Results and Discussion}

\subsection{Water Absorption Characteristics}

The water uptake of sapwood and heartwood filled PVC composites at different periods of immersion are shown in Table 2 and Fig. 1. It was observed that independent of wood type the water absorption of the $\mathrm{PVC} /$ wood flour composites increases with the increasing of wood content. This behavior was expected since the water absorption of these composites is mainly due to the presence of wood, because the PVC matrix absorbs little water and the wood contains numerous hydroxyl groups $(-\mathrm{OH})$, which are available for interaction with water molecules by hydrogen bonding.

Wood interacts with water not only on the surface, but also in the bulk. There are three main regions in the composite where the adsorbed water can reside: the lumen, the cell wall and the gaps between wood flour and PVC in the case of weak interface adhesion is found [14], but for the composites studied in this work, the found low water absorption values indicate that the wood flour was satisfactorily encapsulated in the PVC matrix, suggesting that no significant change occurs in the microstructure of the composites. 
Table 2

Effect of time of immersion and wood type on water absorption of different PVC/wood flour composites

\begin{tabular}{|l|c|c|c|c|c|c|c|c|c|c|c|}
\hline \multirow{1}{*}{ Samples } & \multicolumn{1}{|c|}{$\begin{array}{c}\text { W } \\
\mathrm{h}\end{array}$} & $\begin{array}{c}1 \\
\text { week }\end{array}$ & $\begin{array}{c}2 \\
\text { weeks }\end{array}$ & $\begin{array}{c}3 \\
\text { weeks }\end{array}$ & $\begin{array}{c}4 \\
\text { weeks }\end{array}$ & $\begin{array}{c}5 \\
\text { weeks }\end{array}$ & $\begin{array}{c}6 \\
\text { weeks }\end{array}$ & $\begin{array}{c}7 \\
\text { weeks }\end{array}$ & $\begin{array}{c}8 \\
\text { weeks }\end{array}$ & $\begin{array}{c}9 \\
\text { weeks }\end{array}$ & $\begin{array}{c}10 \\
\text { weeks }\end{array}$ \\
\hline PVC Compound & 0.035 & 0.091 & 0.136 & 0.148 & 0.159 & 0.182 & 0.193 & 0.204 & 0.227 & 0.250 & 0.250 \\
\hline $\begin{array}{l}\text { PVC/Sapwood } \\
10 \mathrm{phr}\end{array}$ & 0.104 & 0.230 & 0.276 & 0.345 & 0.369 & 0.438 & 0.472 & 0.506 & 0.529 & 0.580 & 0.580 \\
\hline $\begin{array}{l}\text { PVC/Sapwood } \\
25 \mathrm{phr}\end{array}$ & 0.191 & 0.416 & 0.495 & 0.607 & 0.675 & 0.753 & 0.832 & 0.900 & 0.922 & 0.967 & 1.023 \\
\hline $\begin{array}{l}\text { PVC/Sapwood } \\
40 \mathrm{phr}\end{array}$ & 0.259 & 0.562 & 0.675 & 0.843 & 0.933 & 1.068 & 1.170 & 1.270 & 1.293 & 1.371 & 1.439 \\
\hline $\begin{array}{l}\text { PVC/Heartwood } \\
10 \mathrm{phr}\end{array}$ & 0.116 & 0.254 & 0.312 & 0.369 & 0.415 & 0.462 & 0.490 & 0.542 & 0.554 & 0.577 & 0.600 \\
\hline $\begin{array}{l}\text { PVC/Heartwood } \\
25 \mathrm{phr}\end{array}$ & 0.182 & 0.420 & 0.512 & 0.625 & 0.682 & 0.773 & 0.850 & 0.920 & 0.966 & 0.989 & 1.057 \\
\hline $\begin{array}{l}\text { PVC/Heartwood } \\
40 \mathrm{phr}\end{array}$ & 0.257 & 0.593 & 0.716 & 0.894 & 1.006 & 1.129 & 1.240 & 1.350 & 1.397 & 1.453 & 1.554 \\
\hline
\end{tabular}

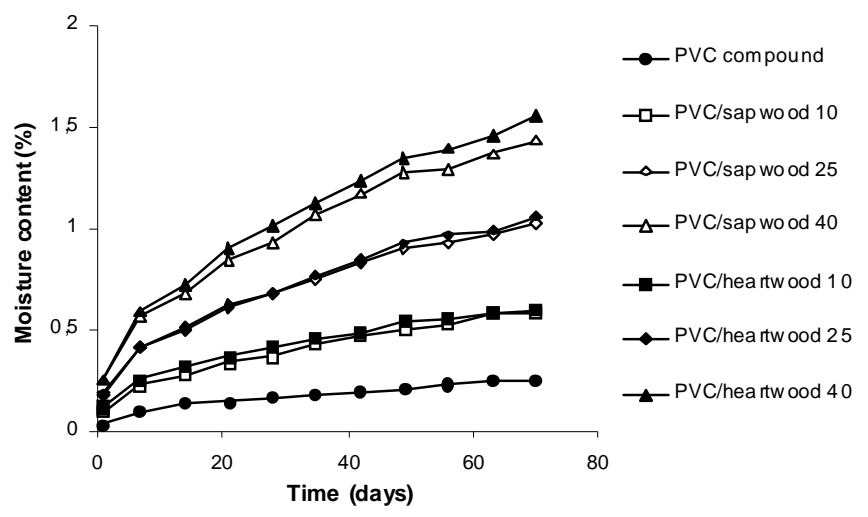

Fig. 1. Water absorption behavior of PVC/wood flour composites as a function of wood type, wood content and time of immersion

Concerning the two wood flour types (heartwood and sapwood), no important difference in moisture absorption ability was found. However slightly higher values of moisture were observed for PVC/heartwood composites, independent of the wood content, as can be seen in Fig. 1. This slight difference is due to the fact that both wood types (heartwood and sapwood) differ in terms of chemical constituent proportions: cellulose, hemicelluloses, lignin, and extractives (Table 3) [16], which can cause differences on the adhesion between wood flour and PVC matrix. In addition, the higher cellulose proportion in the heartwood probably contributes to a great water absorption in the PVC/heartwood composites, since cellulose is a very polar component present in the wood.
Table 3

\section{Chemical composition of the sapwood and heartwood from Angelim Pedra [16]}

\begin{tabular}{|l|c|c|}
\hline \multicolumn{1}{|c|}{ Substances } & $\begin{array}{c}\text { Sapwood } \\
\text { content, \% w/w }\end{array}$ & $\begin{array}{c}\text { Heartwood } \\
\text { content, \% w/w }\end{array}$ \\
\hline Cellulose & 41.84 & 42.77 \\
\hline Hemicelluloses & 14.85 & 13.10 \\
\hline Lignin & 35.60 & 38.67 \\
\hline Extractives & 7.36 & 5.32 \\
\hline Ashes* & 0.35 & 0.14 \\
\hline
\end{tabular}

* Ca, K, Mg, sulfates, phosphates, silicates, carbonates, etc.

The PVC compound and PVC/sapwood composites containing $10 \mathrm{phr}$ of wood showed saturation point (where no more water was absorbed and the water content in the samples remained the same) after 63 days, which correspond to $0.25 \%$ and $0.58 \%$ weight gain respectively, compared to the dry samples. These values are considered very low, since the fiber saturation point (FPS) for most species is between $27 \%$ and $30 \%$ [1]. The other samples continued to absorb water at the end of the test, as shown in Fig. 1.

These results confirm that the composites prepared in this study, especially with $10 \mathrm{phr}$ of wood flour, are a good alternative for wood plastic composites that need to be subjected to damp places, such as the interior of bathrooms, wood decks, food packaging, etc, since the water absorption of these materials was considerably lower. 


\subsection{Impact Strength}

Notched impact strength for PVC/wood flour composites are reported in Fig. 2 and Table 4. The results obtained show that impact property of the composites changed considerably at low wood content (10 phr). It was found that independent of wood type, the filler addition causes reduction in toughness of the PVC composites. The PVC composite with $10 \mathrm{phr}$ of wood flour content showed a reduction of approximately $60 \%$ in impact strength, while those prepared with 25 and 40 phr of wood flour content presented a similar result with approximately $75 \%$ decrease in impact strength. This decrease of deformational energy absorption ability is frequently reported in the literature [19-23] and can be attributed to the following reasons: (1) wood, which is a rigid material, inhibits toughness ability of polymer phase; (2) wood acts as a discontinuity in the PVC matrix of the composites resulting in a decrease in material homogeneity, thus, weakening the material; (3) possible interfacial defects lead to poor stress transfer between polymer matrix and filler [24-26].

Table 4

Impact strength of PVC compound and PVC/wood flour composites

\begin{tabular}{|l|c|}
\hline \multicolumn{1}{|c|}{ Samples } & Impact strength, J/m \\
\hline PVC Compound & $49.5 \pm 2.1$ \\
\hline PVC / Sapwood 10 phr & $18.6 \pm 1.3$ \\
\hline PVC / Sapwood 25 phr & $11.7 \pm 0.7$ \\
\hline PVC / Sapwood 40 phr & $11.7 \pm 0.4$ \\
\hline PVC / Heartwood 10 phr & $20.8 \pm 1.1$ \\
\hline PVC / Heartwood 25 phr & $13.3 \pm 1.1$ \\
\hline PVC / Heartwood 40 phr & $11.8 \pm 0.7$ \\
\hline
\end{tabular}

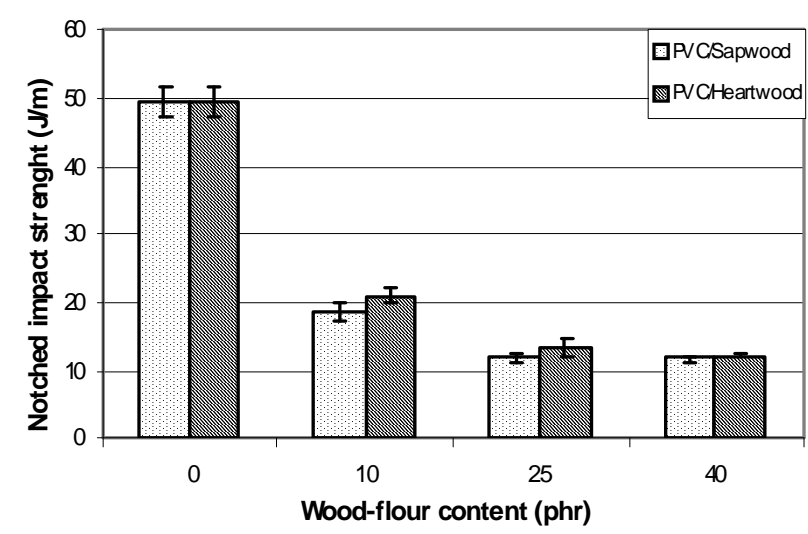

Fig. 2. Impact strength of PVC/wood flour composites as a function of wood type and wood content

\section{Conclusions}

This work studied the effect of wood type and content on water absorption and impact strength of $\mathrm{PVC} /$ wood flour composites.

The results showed that the composites prepared with both wood types have very similar values of absorbed moisture, but the composites prepared with sapwood showed slightly lower ability to absorb water. Although the water uptake of all composites increases with the increasing of time and wood content, their values remain practically negligible as compared to control samples, common wood-based composites reported in literature and solid woods, indicating that the composites prepared with wood from Angelin Pedra are a good alternative to PVC/ wood composites that are exposed to humid environments.

From the impact test results, it was seen that the impact strength was affected by wood content and less by wood type. The composites containing $10 \mathrm{phr}$ of wood flour showed a reduction of approximately $60 \%$ and the composites with 25 and $40 \mathrm{phr}$ wood flour presented a similar behavior, showing $75 \%$ decrease in the impact strength.

In general, the composites containing $10 \mathrm{phr}$ of wood flour content showed better performance in both water absorption and impact behaviors.

\section{Acknowledgements}

The authors would like to thank the CNPq for the financial support of this work and the University of Mato Grosso for providing the wood samples.

\section{References}

[1] Morrell J.: Int Biodeterior Biodegrad., 2002, 49, 253.

[2] Hristov V., Lach R. and Grellmann W.: Polym. Test., 2004, 23, 581 .

[3] Nygard P., Tanem B., Karlsen T. et al.: Compos. Sci. Techn., $2008, \mathbf{6 8}, 3418$.

[4] Colom X., Carrasco F., Pages P. and Canavate J.: Compos. Sci. Techn., 2003, 63, 161.

[5] Jiang H. and Kamdem D.: J. Vinyl Add. Techn., 2004, 10, 59.

[6] Bengtsson M. and Oksman K.: Compos. Sci. Techn., 2006, 66, 2177.

[7] Valle G., Tavares M., Luetkmeyer L. and Stael G.: Macromol. Symp., 2007, 258, 113.

[8] Tserki V., Zafeiropoulos N., Simon F. and Panayiotou C.: Composites A, 2005, 36, 1110.

[9] Yang H., Wolcott M., Kim H. et al.: Compos. Struct., 2007, 79, 369 .

[10] Zheng Y., Cao D., Wang D. and Chen J.: Composites A, 2007, 38, 20.

[11] Bledzky A., Letman M., Viksne A. and Rence L.: Composites A, 2005, 36, 789.

[12] Shi S. and Gardner D.: Composites A, 2006, 37, 1276. 
[13] Bledzki A. and Faruk O.: Compos. Sci. Techn., 2004, 64, 693.

[14] Bledzki A. and Gassan J.: Progr. Polym. Sci., 1999, 24, 221.

[15] Saheb D. and Jog J.: Adv. Polym. Techn., 1999, 18, 351.

[16] Iulianelli G.: PhD thesis, Universidade Federal do Rio de Janeiro, Brazil 2008.

[17] Rocha G., Silva F., Curvelo A. and Araujo J.: Brazilian Symposium on the Chemistry of Lignins and other Wood Components, Curitiba, Brazil 1997, 3.

[18] Rocha G.: PhD thesis, Universidade de Sao Paulo, Brazil 2000.

[19] Cui Y., Lee S., Noruziaan B. et al.: Composites A, 2008, 39, 655 .

[20] Hillig E., Freire E., Carvalho G. et al.: Ciencia Florestal, 2006, 16, 343.

[21] Jacoby P., Sullivan R. and Crostic W.: ANTEC, 2001, 1991. [22] Kuan C., Kuan H., Ma C. and Huang C.: Composites A, 2006, 37, 1696.

[23] Vianna W., Correa C. and Razzino C.: Polimeros: Ciencia e Tecnologia, 2004, 14, 339.

[24] Amim P.: PhD thesis, Universidade Federal do Rio de Janeiro, Brazil 2006.

[25] Rodolfo A.: PhD thesis, Universidade da Sao Paulo, Brazil 2005.

[26] Sombatsompop N. and Chaochanchaikul K.: Polym. Intern., 2004, 53, 1210.

\section{ВОДОПОГЛИНАННЯ ТА УДАРНА В'ЯЗКІСТЬ КОМПОЗИТІВ ПВХ/ДЕРЕВИННА МУКА}

Анотація. Методом компресійного формування $з$ використанням оболоні і сериевини Angelin Pedra як наповнювача приготовлено композити ПВХ/деревинна мука. Проведено тести зразків композитів на занурення у воду та ударну в'язкість. Показано, шуо водопоглинання всіх композитів зростає зі збільшенням тривалості занурення і вмісту деревини. Встановлено, цуо отримані величини є значно нижчими порівняно із контрольними зразками з простої деревини та композитами деревина-пластик, які описані в літературі. Композити ПВХ/ оболонь характеризуються вищими величинами водопоглинаючої здатності завдяки різниці у співвідношенні компонентів. ПВХ і композит ПВХ/оболонь, щчо містить 10 мас.част. деревинної муки, виявляють найбільшу водопоглинаючу здатність протягом 63 днів, щзо становить, відповідно, 0,25 і 0,58\% приросту ваги. В тесті на ударну в'язкість показано, щзо саме вміст деревини, а не ї̈ тип, впливає на отримані результати. Композити, щуо містять 10 мас.част. деревини мають вищу ударну в'язкість, ніж ті, щзо містять 25 i 40 мас.част. деревинної муки. Загалом, найкращі результати за обома дослідженнями виявляють композити з 10 мас.част деревинної муки.

Ключові слова: ПВХ, Angelin Pedra, композити деревинапластик, водопоглинання, ударна в'язкість. 